\title{
STRATEGI PERENCANAAN DAN PENGEMBANGAN OBJEK WISATA (STUDI KASUS PANTAI PANGANDARAN KABUPATEN CIAMIS JAWA BARAT)
}

\author{
Marceilla Hidayat \\ Politeknik Negeri Bandung
}

\begin{abstract}
Tourism can be defined as a whole activity by people who do traveling to stay in one place out of the daily activities for not more than one year for leisure, business, and other purpose. Ecotourism as mentioned on UU No.9 year 1990, article 16 as an objects groups for an attractive tourism can be defined as a unique travel at national park, forest and nature tourism. Bay tourism and marine tourism is a part of Ecotourism. Marine tourism development in general is an effort for developing and using tourism object and marine tourism in Indonesian sea. The consumers behavior patterns from the tourist, they are not focus on leisure enjoying sun, sea and sand but change to higher tourism, that is enjoying the product or cultural creation and heritage. Than nature or ecotourism from one place to other country. This change need to be taken care with a lot of development tourism product also promotion on government and self investor. Marine tourism activities will need a big investment, condition, and law. To handle all this complex problems with optimal, will need to arrange regulation in order using the potential of the sea for tourism activities in marine tourism development. Indonesia so rich with marine assets that can be use or oriented, so that the marine tourism development paradigm must be handle soon with the regulation from all parties, to explore all marine tourism potential through strategic planning with obeying the save principal.
\end{abstract}

Keywords: Strategy, Planning, Development.

\section{PENDAHULUAN}

\subsection{Latar Belakang}

Pariwisata di Indonesia menurut UU

Kepariwisataan No. 9 tahun 1990 pasal 1 (5) adalah segala sesuatu yang berhubungan dengan wisata serta usaha-usaha yang terkait di bidangnya. Pada dasarnya Indonesia umumnya memiliki kekayaan bahari yang berlimpah, yang mencakup kehidupan sekitar 28 ribu species flora, 350 species fauna, 110 ribu species mikroba, serta sekitar 600 species terumbu karang. Keanekaragaman terumbu karang di Indonesia mencapai 600 species dari 400 genera, jauh lebih kaya dari yang dikandung Laut Merah yang hanya memiliki 40 species. Laut Indonesia memiliki ratusan titik harta karun. Benda-benda berharga itu berasal dari muatan kapal yang tenggelam.

Bagi Indonesia wilayah pesisir memiliki arti strategis karena merupakan wilayah peralihan antara ekosistem darat dan laut, serta memiliki potensi sumberdaya alam dan jasajasa lingkungan yang sangat kaya. Kekayaan sumberdaya tersebut menimbulkan daya tarik bagi berbagai pihak untuk memanfaatkan sumberdayanya dan berbagai instansi untuk meregulasi pemanfaatannya.

Potensi objek dan daya tarik di Propinsi Jawa Barat sangat beragam dan tersebar di kabupaten/kota di Jawa Barat. Objek dan daya tarik wisata tersebut telah menarik kunjungan tidak hanya wisnus tetapi juga wisman. Wisata rekreasi berbasis alam menjadi daya tarik utama, berdasarkan data jumlah kunjungan wisatawan ke objek dan daya tarik wisata yang terdapat di Jawa Barat, dimana tercatat ada 7 objek wisata yang memiliki jumlah kunjungan terbanyak, yakni Kebun Raya Bogor (Kota Bogor), Air Panas Ciater (Kab Subang), Makam Sunan Gunung Jati (Kab Cirebon), Kebun Binatang Bandung (Kota Bandung), Taman Safari Indonesia (Kab Bogor), Pantai Pangandaran (Kab Ciamis) serta Gunung Tangkuban Parahu (Kab. Bandung).

Diluar dari jumlah kunjungan terbanyak, dilain hal terdapat ketidakpuasan wisatawan yang tercemin dari sikap 20 biro perjalanan wisata (BPW) yang mencoret objek wisata primadona Jabar itu dari paket wisata yang mereka buat. Faktor-faktor tersebut akan menjadikan pembangunan ataupun pengembangan objek wisata Pantai Pangandaran belum dilaksanakan secara maksimal, hal ini dapat dilihat dari data kunjungan wisatawan kawasan Pangandaran dalam kurun waktu 2000 - 2005 mengalami penurunan yang signifikan. 
TABEL 1

JUMLAH KUNJUNGAN WISATAWAN KE PANGANDARAN

\begin{tabular}{|c|c|}
\hline Tahun & Jumlah Pengunjung \\
\hline 2000 & 1.462 .525 \\
\hline 2001 & 888.816 \\
\hline 2002 & 1.162 .255 \\
\hline 2003 & 1.030 .265 \\
\hline 2004 & 613.845 \\
\hline 2005 & 423.687 \\
\hline
\end{tabular}

Sumber : Litbang Kompas, 2006

Kerusakan lingkungan dan penurunan jumlah wisatawan, yang ditandai dengan dihilangkannya Pangandaran dari paket-paket wisata anggota ASITA menunjukkan bahwa Pangandaran telah memasuki fase stagnasi (butler, 1980), sehingga daerah wisata tersebut memiliki dua pilihan, memasuki fase penurunan atau memperbaiki diri menuju fase pertumbuhan kedua (rejuvenasi). Sehingga saat ini pangandaran harus menentukan pilihan : ditinggalkan wisatawan/pasar atau segera memperbaiki diri.

Proses pengembangan yang tidak terencana dengan baik akan menyebabkan daerah wisata mencapai fase stagnasi dalam jangka waktu yang pendek. Pangandaran dalam hal ini, mencapai fase stagnasi dalam jangka waktu sekitar 25 tahun, dengan masalah yang sudah demikian kompleks. Sebagai sebuah system, perencanaan dan penyelesaian masalah dalam pariwisata harus diselesaikan secara komprehensif dan terintegrasi dengan melibatkan berbagai sektor. Oleh karena itu, paper ini akan mengupas: STRATEGI PERENCANAAN DAN PENGEMBANGAN OBJEK WISATA (STUDI KASUS PANTAI PANGANDARAN KABUPATEN CIAMIS JAWA BARAT)

\subsection{Rumusan Masalah}

1. Bagaimana kondisi aktual (fisik dan nonfisik) aspek pengembangan wisata bahari di objek wisata pantai pangandaran.

2. Bagaimana analisis kebijakan pengembangan objek wisata pantai Pangandaran sebagai strategi perencanaan pengembangan wisata bahari.

3. Bagaimana aktivitas wisata pantai Pangandaran sebagai daya tarik pengunjung yang mempengaruhi kepuasan wisatawan Pantai Pangandaran serta analisis pasar produk wisata pantai Pangandaran sebagai strategi perencanaan pengembangan wisata bahari.

4. Bagaimana strategi perencanaan pengembangan pariwisata berkelanjutan
(Sustainable Tourism) dari objek wisata Pantai Pangandaran dalam rangka pengembangan wisata bahari.

\section{KAJIAN PUSTAKA}

\subsection{Kebijakan Pariwisata}

Menurut Goeldner il. ali es., tourism policy adalah:

Suatu kelompok peraturan, ketentuan, tujuan dan strategi untuk pengembangan/promosi, yang menyediakan suatu kerangka untuk mengambil keputusan secara kolektif dan invidual yang mempengaruhi pengembangan pariwisata secara langsung, serta aktifitas harian dalam suatu destinasi.

Dapat dikatakan bahwa kebijakan pariwisata mencoba untuk menyediakan pengalaman pengunjung yang berkualitas dan memberikan "profit"/keuntungan kepada para stakeholder destinasi sambil memastikan bahwa destinasi tidak dikompromi dalam integritas lingkungan, sosial dan budaya.

Terdapat beberapa fungsi dari kebijakan pariwisata, yakni sebagai berikut :

Mendefinisikan "rules of the game" yakni kerangka yang menjadi dasar untuk "operatoroperator" pariwisata.

1. Menentukan aktifitas dan perilaku yang diharapkan.

2. Memberikan suatu arahan (direction) dan bimbingan untuk semua stakeholder pariwisata di suatu destinasi

3. Memfasilitasi consensus berdasarkan strategi dan tujuan yang spesifik untuk suatu daerah destinasi tertentu.

4. Memberikan kerangkan untuk diskusi public/swasta tentang peran dan kontribusi dari sektor pariwisata kepada ekonomi dan kepada masyarakat secara umum.

5. Memberikan kerangka untuk diskusi publik/swasta tentang peran dan kontribusi dari sektor pariwisata kepada ekonomi dan kepada masyarakat secara umum.

6. Memungkinkan pariwisata bisa berhadapan bersama dengan sektor-sektor lain dari ekonomi.

\subsection{Perencanaan Pariwisata}

Kebijakan pariwisata memberikan filsafat dasar untuk pembangunan dan menentukan arah pengembangan pariwisata di destinasi tersebut untuk masa depan. Sebuah destinasi dapat dikatakan akan melakukan pengembangan wisata jika sebelumnya sudah ada aktivitas wisata. Dalam pelaksanaan pengembangan, perencanaan merupakan faktor 
yang perlu dilakukan dan dipertimbangkan. Menurut Inskeep (1991:29), terdapat beberapa pendekatan yang menjadi pertimbangan dalam melakukan perencanaan pariwisata, diantaranya:

1. Continous Incremental, and Flexible Approach, dimana perencanaan dilihat sebagai proses yang akan terus berlangsung didasarkan pada kebutuhan dengan memonitor feed back yang ada.

2. System Approach, dimana pariwisata dipandang sebagai hubungan sistem dan perlu direncanakan seperti dengan tehnik analisa sistem.

3. Comprehensive Approach, berhubungan dengan pendekatan sistem diatas, dimana semua aspek dari pengembangan pariwisata termasuk didalamnya institusi elemen dan lingkungan serta implikasi sosial ekonomi, sebagai pendekatan holistik.

4. Integrated Approach, berhubungan dengan pendekatan sistem dan keseluruhan dimana pariwisata direncanakan dan dikembangkan sebagai sistem dan keseluruhan dimana pariwisata direncanakan dan dikembangkan sebagai sistem yang terintegrasi dalam seluruh rencana dan total bentuk pengembangan pada area.

5. Environmental and sustainable development approach, pariwisata direncanakan, dikembangkan, dan dimanajemeni dalam cara dimana sumber daya alam dan budaya tidak mengalami penurunan kualitas dan diharapkan tetap dapat lestari sehingga analisa daya dukung lingkungan perlu diterapkan pada pendekatan ini.

6. Community Approach, pendekatan yang didukung dan dikemukakan juga oleh Peter Murphy (1991) menekankan pada pentingnya memaksimalkan keterlibatan masyarakat lokal dalam perencanaan dan proses pengambilan keputusan pariwisata, untuk dapat meningkatkan yang diinginkan dan kemungkinan, perlu memaksimalkan partisipasi masyarakat dalam pengembangan dan manajemen yang dilaksanakan dalam pariwisata dan manfaatnya terhadap sosial ekonomi.

7. Implementable Approach, kebijakan pengembangan pariwisata, rencana, dan rekomendasi diformulasikan menjadi realistis dan dapat diterapkan, dengan tehnik yang digunakan adalah tehnik implementasi termasuk pengembangan, program aksi atau strategi, khususnya dalam mengidentifikasi dan mengadopsi.
8. Application of systematic planning approach, pendekatan ini diaplikasikan dalam perencanaan pariwisata berdasarkan logika dari aktivitas.

Goals biasanya termasuk aspek-aspek seperti meningkatkan kepuasan pengunjung, diversifikasi pasar pariwisata, meningkatkan kontribusi pariwisata kepada ekonomi local, dan mengembangkan potensi pariwisata suatu daerah. Sementara objectives adalah lebih spesifik (khusus) dan berhubungan dengan tindakan-tindakan yang aktual. Objectives bertujuan untuk mengarahkan tindakan yang akan membantu mencapai goal-goal pembangunan. Jadi objectives harus lebih realistis, dapat diukur dan mampu dicapai dalam jangka waktu yang ditentukan.

\section{GAMBAR 1}

TOURISM STRATEGY

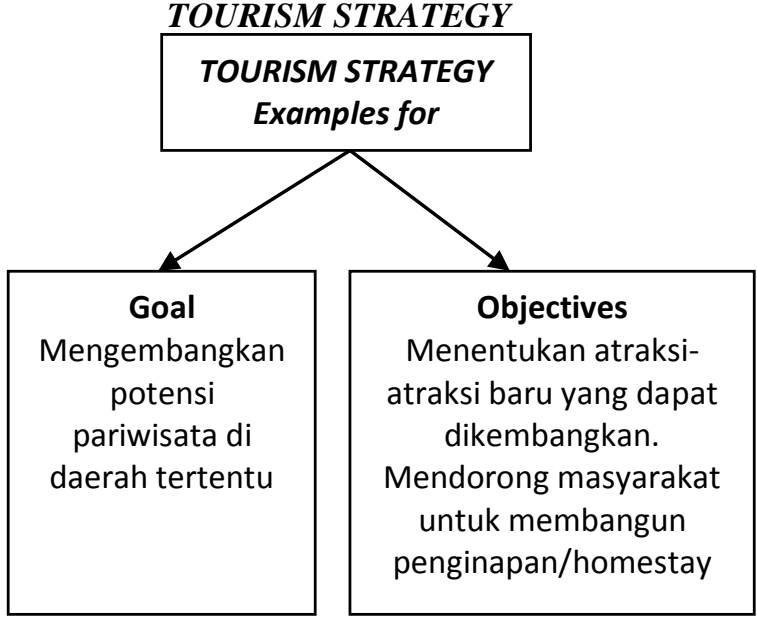

Sumber : Godfrey \& Clarke , 113

Menurut Godfrey \& Clarke "Goals and Objectives" yang realistis adalah inti untuk pengembangan pariwisata yang bersukses. Tourism Action Steps menyangkut siapa, apa, dimana dan bagaimana yang menjelaskan bagaimana caranya goals and objectives akan dilaksanakan. Tindakan pariwisata menyatakan apa yang akan dilakukan, kapan akan dilakukan dan oleh siapa. Tourism Action Steps harus jelas dan mempunyai jangka waktu yang ditentukan dan tujuan yang diharapkan. Pelaksanaan tindakan itu dapat didelegasikan secara individu atau berkelompok.

Menurut Godfrey and Clarke proses membentuk strategi pariwisata terdiri dari tiga langkah, yaitu:

1. Identifying Opportunities and Constraints (Based on an evacuation of supply and demand).

2. Setting development Goals and Objective (Addressing issues needing attention in the short, medium and longer term). 
3. Define a series of action steps (Designed to achieve the goals and objectives within some specified time frame).

\subsection{Konsep Perencanaan Strategis}

Perencanaan adalah proses kumpulan kebijakan dan bagaimana mengimplementasikannya. Pendapat yang sama dikemukakan juga oleh Claire A. Gunn (1993: 141) yang menegaskan bahwa ada beberapa hal penting di dalam fungsi kebijakan regional dan lokal sebagai alat yang sangat penting di dalam kegiatan kepariwisataan, yaitu antara lain: Pertama, perencanaan harus mampu meningkatkan pertumbuhan yang berkualitas, membutuhkan perubahanperubahan yang membangun, disamping pengembangan lokasi yang potensial untuk mengembangkan kualitas atraksi yang dapat dijual. Kedua, kebijakan kepariwisataan harus lebih memiliki peranan penting dari kegiatan promosi, kebijakan tersebut harus didukung oleh penelitian. Ketiga, perencanaan kepariwisataan memerlukan kerjasama publik dan privat agar segala harapan stakeholders bisa terpenuhi. Keempat, perencanaan kebijakan regional dan lokal harus dapat memperkuat semua perencanaan, mendukung pembangunan pariwisata yang baik hingga pada tingkat destinasi. Kelima, perencanaan kebijakan regional dan lokal harus dapat merangsang usaha (bisnis) untuk memberikan sumbangsihnya kepada pembangunan daerah. Keenam, kebijakan harus dapat menghubungkan bisnis dengan pemerintah dan non-profit atraction, seperti kebijakan perencanaan usaha atraksi (alam dan budaya) harus didukung oleh bisnis perjalanan dan akomodasi lainnya.

\section{GAMBAR 2 \\ TOURISM STRATEGIC PLANNING PROCESS}
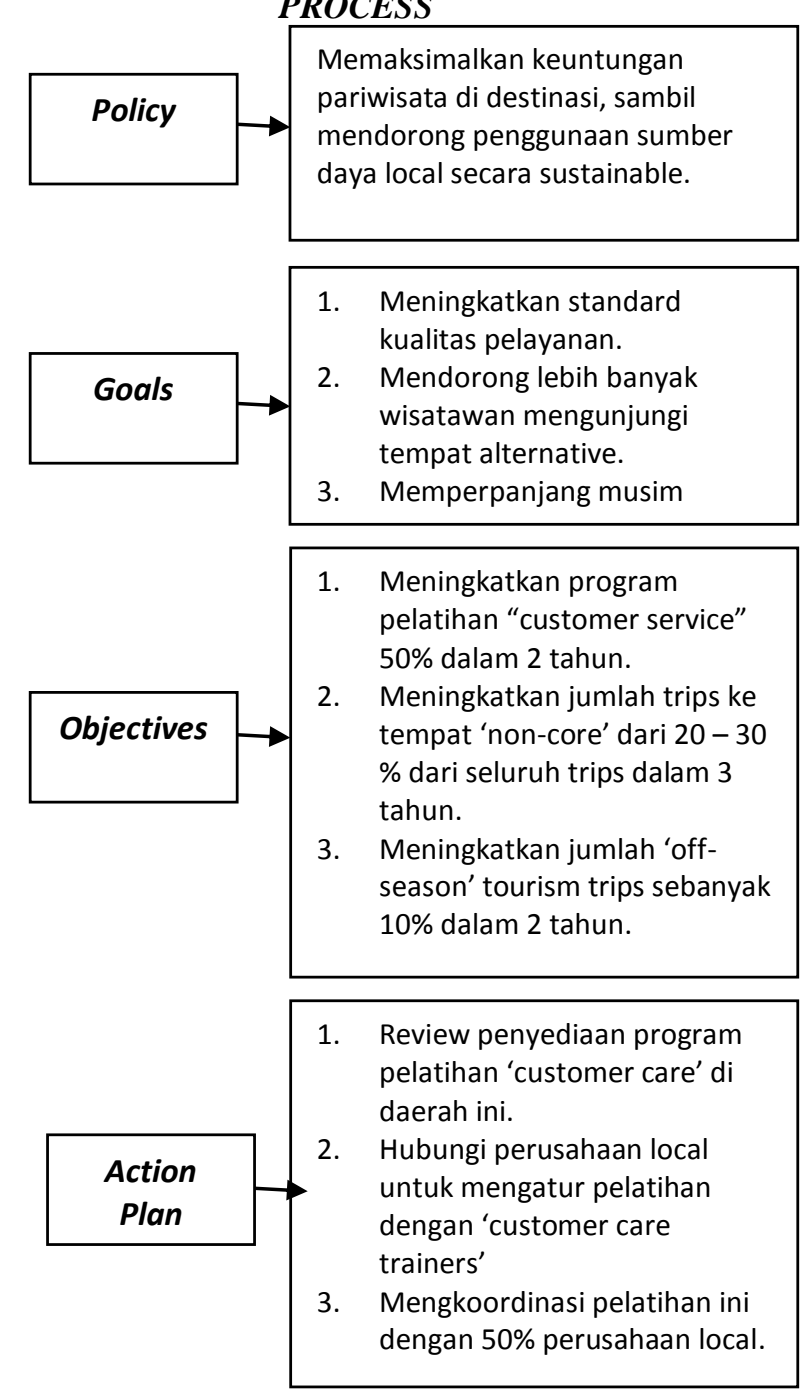

\subsection{Konsep dan Prinsip 'Sustainable Tourism, \\ Sustainable Tourism (pariwisata} berkelanjutan) dan Sustainable development (pembangunan berkelanjutan) adalah istilah yang mengakibatkan bermacam-macam tanggapan/respons dari manajer-manajer, perencana-perencana pariwisata, serta pembela/advokat lingkungan, baik skeptis sampai yang memperhatikan.

Menurut WTO dalam agenda 21 untuk industri travel dan pariwisata menyatakan :

Sustainable tourism development
memenuhi kebutuhan wisatawan dan
masyarakat daerah tujuan wisata
sambil melindungi ran
mengembangkan peluang pada masa
depan. Dipandang sebagai sesuatu
yang mengarahkan ke manajemen,
seluruh sumber daya dengan cara


dimana kebutuhan ekonomi, sosial dan estetik dapat dipenuhi bersama integritas budaya, proses-proses ekologi yang esensial, diversitas biologi dan sistem-sistem mendukung kehidupan tetap dipelihara.

Isu-isu strategis dalam Sustainable Tourism adalah sebagai berikut:

1. Meningkatkan tanggung jawab Stakeholder Corporate

2. Menghasilkan Bentuk pariwisata yang cocok

3. "Sustaining" Sumber Daya Sosial dan Budaya

4. "Sustaining" Lingkungan Alam

5. Kebutuhan atas rencana yang efektif untuk Perencanaan Daerah Tujuan Wisata

6. Peranan "Carrying Capatities" dan indikator-indikator dalam Sustainable Tourism.

7. Menghindari konflik

8. Peningkatan Keterlibatan Masyarakat

9. Pengarahan untuk masa depan.

\subsection{Konsep dan Strategi Pengembangan Daerah Tujuan Wisata}

Sebuah destinasi dapat dikatakan akan melakukan pengembangan wisata jika sebelumnya sudah ada aktivitas wisata. Untuk dapat meningkatkan potensi pariwisatanya, yang perlu dilakukan adalah merencanakan pengembangan wisata agar dapat lebih baik dari sebelumnya. Tiga prinsip utama dalam sustainability development (McIntyre, 1993: 10):

1. Ecological Sustainability, yakni memastikan bahwa pengembangan yang dilakukan sesuai dengan proses ekologi, biologi, dan keragaman sumber daya ekologi yang ada.

2. Social and Cultural Sustainability, yaitu memastikan bahwa pengembangan yang dilakukan memberi dampak positif bagi kehidupan masyarakat sekitar dan sesuai dengan kebudayaan serta nilai-nilai yang berlaku pada masyarakat tersebut.

3. Economic Sustainability, yaitu memastikan bahwa pengembangan yang dilakukan efisien secara ekonomi dan bahwa sumber daya yang digunakan dapat bertahan bagi kebutuhan di masa mendatang.

Sementara itu dilain hal, sektor pariwisata terdiri atas beberapa komponen yang berbeda yang harus benar-benar dimengerti dan direncanakan dan dikembangkan secara terintegrasi dalam masyarakat. Segalanya untuk kenyamanan perencanaan pariwisata dalam masyarakat itu sendiri, komponen-komponen pendekatan pengembangan pariwisata menurut Edward Inskeep (1998) adalah sebagai berikut:

\section{GAMBAR 3}

KOMPONEN PERENCANAAN/ PENGEMBANGAN PARIWISATA

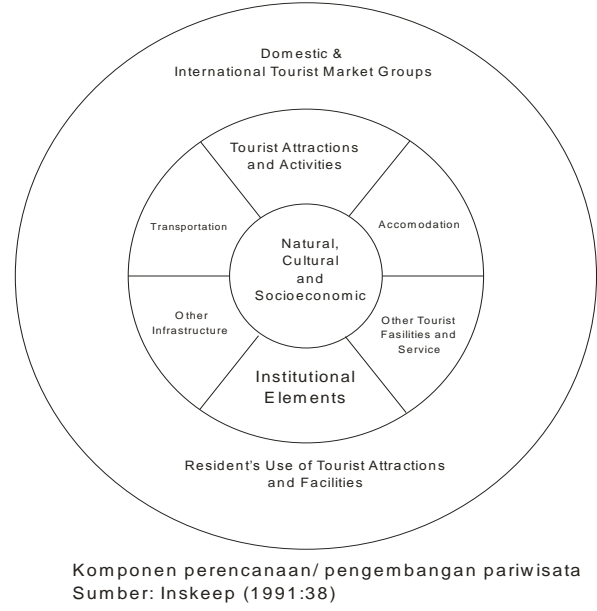

III. METODE PENELITIAN

\subsection{Objek Penelitian}

Unit observasi dalam penelitian ini adalah Dinas Pariwisata Kabupaten Ciamis sebagai regulator dalam perencanaan kegiatan pariwisata bahari. Aspek penelitian ini difokuskan pada strategi perencanaan pariwisata. Sedangkan unit analisis dalam penelitian ini adalah kawasan pantai Pangandaran sebagai objek daya tarik wisata di Kabupaten Ciamis Jawa Barat.

\subsection{Desain Penelitian}

Penelitian ini bersifat deskriptif, dilakukan untuk mendapatkan gambaran atau deskripsi tentang penilaian aspek-aspek pengembangan wisata bahari yang dilakukan melalui perhitungan statistic, kemudian dilakukan analisis pengembangan objek wisata yang dilakukan menggunakan teknik analisis SWOT, yaitu analisis untuk menemukan kekuatan, kelemahan, peluang dan ancaman terhadap produk, pasar, kebijakan dan program pemasaran.

Metode yang digunakan dalam peneltian ini adalah metode survey, dimana informasi diperoleh dari responden yang dikumpulkan secara empiric untuk memperoleh pendapat dari sebagian populasi terhadap obyek penelitian. Berdasarkan jenis data dan analisisnya, desain penelitian ini merupakan sebagai gabungan data penelitian kuantitatif serta data kualitatif. 


\subsection{Operasionalisasi Variabel}

Pengukuran terhadap variabel penelitian dilakukan dengan cara menguraikan variable penelitian ke dalam operasionalisasi variabel penelitian yang terdiri atas variable, sub variabel, dimensi dan indikator yang masing-masing dapat diuraikan sebagai berikut

TABEL 2

OPERASIONALISASI VARIABEL

\begin{tabular}{|c|c|c|}
\hline Variabel & $\begin{array}{c}\text { Sub } \\
\text { Variabel }\end{array}$ & Indikator \\
\hline \multirow[t]{13}{*}{$\begin{array}{l}\text { Pengembangan } \\
\text { Wisata Bahari }\end{array}$} & $\begin{array}{l}\text { Pangsa } \\
\text { pasar }\end{array}$ & $\begin{array}{ll}\text { - } & \text { Wisatawan } \\
\text { asing } \\
\text { - } \quad \text { Wisatawan } \\
\text { nasional } \\
\text { - } \quad \text { Wisatawan } \\
\text { lokal. }\end{array}$ \\
\hline & $\begin{array}{c}\text { Tourist } \\
\text { Attraction }\end{array}$ & $\begin{array}{ll}- & \text { Nilai sejarah } \\
- & \text { Keaslian }\end{array}$ \\
\hline & & $\begin{array}{ll}- & \text { Panorama } \\
\text { alam } \\
\text { - } \\
\begin{array}{l}\text { Flora \& } \\
\text { fauna }\end{array} \\
\end{array}$ \\
\hline & & - $\quad$ Skala Event \\
\hline & Infrastruktur & - $\quad$ Ketersediaan \\
\hline & & $\begin{array}{ll}\text { - } & \text { Ketersediaan } \\
\text { - } & \text { Kebersihan }\end{array}$ \\
\hline & & - $\quad$ Ketersediaan \\
\hline & Aksesibilitas & $\begin{array}{ll}- & \text { Prasarana } \\
- & \text { Transportasi } \\
- & \text { Kepastian } \\
\end{array}$ \\
\hline & & $\begin{array}{ll}\text { - } & \text { Transportasi } \\
\text { - } & \text { Kepastian }\end{array}$ \\
\hline & $\begin{array}{c}\text { Fasilitas dan } \\
\text { pelavanan }\end{array}$ & - $\quad$ Interprestasi \\
\hline & wisatawan & $\begin{array}{ll}- & \text { Kelengkapan } \\
- & \text { Kualitas } \\
& \text { SDM } \\
\end{array}$ \\
\hline & & $\begin{array}{ll}- & \text { SDM } \\
- & \text { Sistem } \\
& \text { penanganan } \\
\end{array}$ \\
\hline & $\begin{array}{c}\text { Elemen } \\
\text { institusi } \\
\text { (Institutional }\end{array}$ & $\begin{array}{ll} & \text { Kerjasama } \\
\text { - } & \text { Penerimaan } \\
& \text { Masyarakat }\end{array}$ \\
\hline
\end{tabular}

Dari masing-masing variabel, beserta dimensi dan indikator-indikatornya, disusun kuesioner untuk menggali informasi lebih lanjut dengan menggunakan skala likert.

Skala likert digunakan untuk menyatakan sikap seperti pernyataan baik buruk, positif negative, setuju dan tidak setuju maka variable yang akan diukur dijabarkan menjadi subvariabel, kemudian subvariabel, kemudian subvariabel dijabarkan menjadi komponen-komponen yang dapat diukur. Komponen-komponen yang terukur ini kemudian dijadikan sebagai titik tolak untuk penyusun item instrumen yang dapat berupa pertanyaan yang kemudian dijawab oleh responden.

\section{IV.}

\section{PEMBAHASAN}

Hasil penelitian mengenai aspek pengembangan wisata bahari di objek wisata pantai Pangandaran adalah sebagai berikut:

TABEL 3

DESKRIPSI HASIL PENGEMBANGAN WISATA BAHARI

\begin{tabular}{|c|c|c|c|}
\hline NO & INDIKATOR & MEAN & $\begin{array}{c}\text { STD } \\
\text { Deviasi }\end{array}$ \\
\hline 1 & $\begin{array}{l}\text { Kerjasama antar } \\
\text { stakeholder }\end{array}$ & 3.00 & .452 \\
\hline 2 & $\begin{array}{l}\text { Penerimaan } \\
\text { masyarakat }\end{array}$ & 3.06 & .314 \\
\hline 3 & $\begin{array}{l}\text { Kebersihan } \\
\text { makanan dan } \\
\text { minuman }\end{array}$ & 3.26 & .443 \\
\hline 4 & SDM Promosi & 3.26 & .565 \\
\hline 5 & $\begin{array}{l}\text { Pengelolaan } \\
\text { Objek }\end{array}$ & 3.36 & .525 \\
\hline 6 & $\begin{array}{l}\text { Transportasi } \\
\text { didalam objek }\end{array}$ & 3.42 & .642 \\
\hline 7 & $\begin{array}{l}\text { SDM } \\
\text { Pariwisata }\end{array}$ & 3.44 & .501 \\
\hline 8 & $\begin{array}{l}\text { Pelayanan } \\
\text { informasi }\end{array}$ & 3.44 & .675 \\
\hline 9 & $\begin{array}{l}\text { Ketersediaan } \\
\text { fasilitas lainnya }\end{array}$ & 3.46 & .734 \\
\hline 10 & $\begin{array}{l}\text { Ketersediaan } \\
\text { fasilitas } \\
\text { penunjang }\end{array}$ & 3.50 & .647 \\
\hline 11 & $\begin{array}{l}\text { Ketepatan } \\
\text { transportasi } \\
\text { diluar objek }\end{array}$ & 3.52 & .646 \\
\hline 12 & $\begin{array}{l}\text { Ketepatan } \\
\text { transportasi } \\
\text { didalam objek }\end{array}$ & 3.52 & .505 \\
\hline 13 & $\begin{array}{l}\text { Transportasi } \\
\text { diluar objek }\end{array}$ & 3.56 & .644 \\
\hline 14 & $\begin{array}{l}\text { Keistimewaan } \\
\text { atraksi buatan }\end{array}$ & 3.86 & .405 \\
\hline 15 & $\begin{array}{l}\text { Ketersediaan } \\
\text { makanan dan } \\
\text { minuman }\end{array}$ & 3.94 & .424 \\
\hline 16 & Keaslian & 4.00 & .657 \\
\hline 17 & Flora dan fauna & 4.02 & .319 \\
\hline
\end{tabular}




\begin{tabular}{|c|l|c|c|}
\hline NO & INDIKATOR & MEAN & $\begin{array}{c}\text { STD } \\
\text { Deviasi }\end{array}$ \\
\hline 18 & $\begin{array}{l}\text { Ketersediaan } \\
\text { akomodasi }\end{array}$ & 4.24 & .591 \\
\hline 19 & Panorama alam & 4.12 & .385 \\
\hline 20 & $\begin{array}{l}\text { Skala kegiatan } \\
\text { atraksi }\end{array}$ & 4.58 & .499 \\
\hline
\end{tabular}

Sumber : Diolah dari hasil kuesioner, 2006

Berdasarkan tabel tersebut, nilai tertinggi adalah 4.58 yang artinya sangat baik pada indikator skala atraksi dan nilai terendah sebesar 3.00 yang artinya cukup pada indikator kerjasama antar stakeholder. Indikator skala kegiatan atraksi dinilai baik oleh responden diduga dikarenakan sering (hampir setiap tahun) diadakan berbagai acara atau festival di Pangandaran seperti yang baru saja dilaksanakan pada bulan Juli tahun 2006 yaitu festival layang-layang yang bersifat International. Sedangkan untuk indikator kerjasama antar stake holder dinilai rendah oleh responden dimungkinkan karena masih kurangnya jumlah stakeholder yang saling bekerjasama dalam upaya meningkatkan aktivitas pariwisata di Pangandaran.

Menurut data yang sudah diolah, bahwa rata-rata potensi wisata bahari yang ada di objek wisata pantai Pangandaran adalah 3,62 atau dapat dikatakan baik. Dari rata-rata tersebut beberapa indikator yang terdapat di atas rata-rata adalah keistimewaan atraksi buatan, keaslian, panorama alam, flora dan fauna, skala kegiatan atraksi, ketersediaan atraksi.Disamping itu nilai sejarah sebagai keaslian buatan manusia dapat dikatakan baik, dimana objek wisata pantai Pangandaran ini merupakan peninggalan penjajahan dan pernah diduduki oleh tentara Jepang pada saat PD II. Jawaban responden terhadap indikator ketersediaan akomodasi berupa hotel, homestay adalah baik (30\%), baik sekali (16\%), cukup (4\%). Akomodasi merupakan fasilitas yang sangat diperlukan bagi wisatawan sebagai tempat untuk tinggal dan menginap di daerah tujuan wisata yang dikunjunginya (Inskeep, 1998:44). Kemudian untuk indikator transportasi diluar objek dan atau menuju objek wisata pantai Pangandaran adalah baik (26\%), cukup (20\%), Baik sekali (2\%) dan kurang (2\%). Akses utama ke Pangandaran adalah jalan daratan, dimana mayoritas pengunjung/wisatawan adalah naik bis dan mobil pribadi. Serta Ketepatan untuk transportasi tersebut dijawab oleh responden baik (24\%), cukup(22\%), baik sekali (2\%) dan kurang $(2 \%)$.
Pada indikator ketersediaan fasilitas penunjang/spesifik dari responden menyatakan kurang (36\%), cukup (10\%), baik (3\%) dan baik sekali (1\%). Bangunan untuk Visitor Information Center berada di gerbang kawasan wisata Pangandaran dan dipinggir pantai tetapi tidak dipakai, tidak ada papan informasi dan petunjuk jalan masih kurang sekali.

\subsection{Kondisi dan Kegiatan Wisata Bahari Objek Wisata Pantai Pangandaran}

Secara geografis Kabupaten Ciamis terletak pada posisi $108^{\circ} 20^{\prime}-108^{\circ} 40^{\prime} \mathrm{BT}$ dan $7^{\circ} 40^{\prime} 20^{\prime \prime}$ LS. Batas-batas wilayah Kabupaten Ciamis meliputi:

- Sebelah utara : Kabupaten Majalengka dan Kabupaten Kuningan

- Sebelah barat : Kabupaten Tasikmalaya

- Sebelah timur : Propinsi Jawa Tengah

- Sebelah selatan : Samudera Indonesia Kawasan objek wisata pantai Pangandaran telah dibangun dengan kira-kira 2,128 rumah masyarakat dan bangunanbangunan pemerintah, pendidikan, ibadah dan jasa yang melayani masyarakat serta bangunan-bangunan akomodasi dan jasa pariwisata. Tinggi mayoritas bangunan adalah 1 atau 2 lantai, namun ada juga bangunanbangunan hotel sampai dengan 3 lantai. Tempat akomodasi yang termasuk hotel, penginapan dan homestay, serta bangunan rumah makan, restoran dan jasa pariwisata yang lain telah mempengaruhi suasana fisik kawasan ini. Mayoritas dari bangunan yang berkaitan dengan pariwisata terletak di pinggir Pantai Barat dan Pantai Timur dan bagian selatan dari genting tanah.

1. Atraksi Pantai Pangandaran

Objek wisata yang terdiri dari 2 (dua) pantai panjang, yaitu Pantai Barat dan Pantai Timur, dengan keistimewaan utama seperti:

a. Dapat melihat terbit dan terbenamnya matahari dari tempat yang sama.

b. Pantainya landai dengan air yang jernih serta jarak antara pasang dan surut relative lama sehingga memungkinkan orang untuk berenang dengan aman.

c. Mempunyai garis pantai yang luas, sehingga memungkinkan untuk rekreasi rombongan.

d. Suasana desa nelayan yang sangat kental. Aktivitas sehari-hari nelayan dapat dilihat dengan jelas. 
4.2. Kebijakan

Pembangunan

\section{Kepariwisataan}

- Undang-Undang No.22 tahun 1999 jo Undang-Undang No.32 tahun 2004 tentang Otonomi Daerah

- Undang-Undang No. 9 tahun 1990 tentang Kepariwisataan Nasional.

- Perda Propinsi Jawa Barat No. 2 tahun 2003 tentang Tata Ruang Wilayah Propinsi Jawa Barat.

- Perda Kabupaten Ciamis No. 17 tahun 2004 tentang Rencana Strategik Pemerintah Kabupaten Ciamis.

- Perda Kabupaten Ciamis No. 5 tahun 1987 tentang Rencana Zona Objek Wisata Pantai Pangandaran Kawasan Wisata Ciamis Selatan.

- Perda Kabupaten Ciamis No. 20 Tahun 2001 ISUP melalui Surat Edaran Bupati Ciamis 31 Januari 2002 yang dikeluarkan 1 Februari 2002, H. Oma Sasmita; mengenai "Pemindahan pedagang ke pasar wisata Pangandaran 2001", per tanggal 31 Desember yang memuat :

1. Mengembalikan fungsi pantai sebagai objek \& tujuan wisata.

2. Memberikan tata keadilan kepada pengunjung objek wisata.

3. Mewujudkan ketertiban, keamanan, kenyamanan kepada wisatawan \& masyarakat.

\subsection{Objek Dan Daya Tarik Wisata Dan Analisis Pasar}

Untuk pengembangan pembangunan pariwisata di Kabupaten Ciamis berdasarkan Rencana Strategis Tahun 2004-2009, dimana Kabupaten Ciamis memiliki 21 objek wisata yang terbentang mulai dari utara sampai selatan, dengan jenis objek dan daya tarik wisata yang bervariasi dari Objek Wisata Budaya, Objek Wisata Alam dan Objek Wisata Minat Khusus. Pengembangan kepariwisataan di Kabupaten Ciamis termasuk kedalam wilayah Pengembangan Pariwisata Priangan, pengembangannya dibagi dalam 6 (enam) Satuan Kawasan Wisata (SKW), yakni SKW Panjalu, Bojong Galuh, SKW Karang Nini, SKW Pangandaran, SKW Parigi dan SKW Batu Karas. Penelitian terpusat pada SKW Pangandaran-Objek Wisata Pantai Pangandaran (Pantai Timur, Pantai Barat \& Cagar Alam Pananjung).

Segmentasi pasar wisata adalah terhadap wisatawan nusantara maupun wisatawan mancanegara dengan berbagai kegiatan wisata antara lain :

- Berenang/Surfing
- Sightseeing

- Berkemah/Camping

- Penelitian/Research

- Pendidikan dan pelatihan

- Aktivitas pecinta alam

- Piknik/Rekreasi

Kondisi pasar aktual (yang ada) saat ini di objek wisata pantai Pangandaran sebagai berikut :

a. Analisis Aspek Geografis, sebagian besar responden yang berkunjung ke objek wisata pantai Pangandaran berasal dari Jawa Barat, motivasi mereka adalah mencari suhu udara dan suasana pantai yang sejuk dan terdekat bagi mereka.

b. Aspek Demografis, mayoritas pengunjung yang datang ke Pangandaran adalah pria $( \pm$ $57 \%$ ) dan wanita sisanya. Hal ini mengindikasikan bahwa pria mempunyai kecenderungan yang lebih besar akan wisata alam. Rata-rata usia responden yang berkunjung ke Pangandaran berkisar antara 20-29 tahun dengan aktivitas yang beragam seperti : trekking, pendidikan, berkemah, dan lain-lain.

c. Aspek psikografis, wisatawan memiliki tujuan perjalanan ke pantai Pangandaran adalah untuk menikmati keindahan pantai dan menjadi salah satu tujuan yang menyenangkan bagi pengunjung untuk beraktivitas seperti berenang dan berselancar

d. Aspek Perilaku, wisatawan mendapatkan informasi mengenai Pangandaran dari teman/saudara (relasi) yang telah pernah datang mengunjungi objek wisata ini karena mayoritas pengunjung mengungkapkan bahwa tidak mengetahui adanya layanan informasi,

Dari pasar aktual tersebut dapat kita menyusun pasar potensial yang dapat di layani, sebagai berikut:

TABEL 4

SEGMENTASI PASAR POTENSIAL

\begin{tabular}{|c|c|c|}
\hline Aspek & $\begin{array}{c}\text { Pasar } \\
\text { Aktual }\end{array}$ & Pasar Potensial \\
\hline Geografis & $\begin{array}{l}\text { Asal } \\
\text { wisatawa } \\
\text { n dari } \\
\text { daerah } \\
\text { sekitar } \\
\text { Jawa } \\
\text { Barat }\end{array}$ & $\begin{array}{l}\text { Sebagian besar } \\
\text { wisatawan/pengu } \\
\text { njung potensial } \\
\text { berasal dari } \\
\text { seluruh nusantara } \\
\text { Indonesia }\end{array}$ \\
\hline $\begin{array}{l}\text { Demograf } \\
\text { is }\end{array}$ & $\begin{array}{l}\text { Usia 20- } \\
29 \\
\text { Pekerjaan } \\
\text { : Pekerja, }\end{array}$ & $\begin{array}{l}\text { Usia } 20-40 \\
\text { tahun } \\
\text { Pekerjaan : } \\
\text { Eksekutif, }\end{array}$ \\
\hline
\end{tabular}




\begin{tabular}{|c|c|c|}
\hline Aspek & $\begin{array}{c}\text { Pasar } \\
\text { Aktual }\end{array}$ & Pasar Potensial \\
\hline & $\begin{array}{l}\text { mahasisw } \\
\text { a, pelajar. } \\
\text { Jenis } \\
\text { kelamin : } \\
\text { Dominan } \\
\text { pria } \\
\text { Rekan } \\
\text { perjalana } \\
\mathrm{n}: \\
\text { keluarga }\end{array}$ & $\begin{array}{l}\text { pekerja, } \\
\text { mahasiswa, } \\
\text { pelajar. } \\
\text { Jenis kelamin : } \\
\text { Balance Pria \& } \\
\text { wanita } \\
\text { Rekan perjalanan } \\
\text { : Keluarga, rekan } \\
\text { bisnis. }\end{array}$ \\
\hline $\begin{array}{l}\text { Psikografi } \\
\text { s }\end{array}$ & $\begin{array}{l}\text { Motivasi } \\
\text { : melihat } \\
\text { keindaha } \\
\text { n pantai } \\
\text { Suasana } \\
\text { wisata } \\
\text { yang } \\
\text { diharapka } \\
n \text { : tenang } \\
\text { dan sunyi } \\
\text { Aktivitas } \\
: \\
\text { berenang } \\
\& \\
\text { berselanc } \\
\text { ar } \\
\end{array}$ & $\begin{array}{l}\text { Motivasi : } \\
\text { melihat } \\
\text { keindahan pantai, } \\
\text { menikmati event- } \\
\text { event, berkemah. } \\
\text { Suasana wisata } \\
\text { yang diharapkan : } \\
\text { tenang dan sunyi, } \\
\text { nyaman, atraktif. } \\
\text { Aktivitas : } \\
\text { berenang, } \\
\text { berselancar, } \\
\text { parasailing, jetski } \\
\text { dll }\end{array}$ \\
\hline Perilaku & $\begin{array}{l}\text { Sumber } \\
\text { Informasi } \\
: \\
\text { Keluarga/ } \\
\text { teman } \\
\text { Moda } \\
\text { transporta } \\
\text { si: } \\
\text { kendaraa } \\
\text { n pribadi, } \\
\text { bus } \\
\text { pariwisat } \\
\text { a } \\
\text { Bentuk } \\
\text { kunjunga } \\
\text { n yang } \\
\text { dilakukan } \\
: \text { bersama } \\
\text { teman } \\
\text { atau } \\
\text { keluarga. }\end{array}$ & $\begin{array}{l}\text { Sumber } \\
\text { informasi : } \\
\text { keluarga/teman, } \\
\text { relasi bisnis, } \\
\text { perusahaan, web } \\
\text { site dll. } \\
\text { Moda } \\
\text { transportasi : } \\
\text { kendaraan } \\
\text { pribadi, bis } \\
\text { pariwisata, } \\
\text { pesawat udara, } \\
\text { via laut. } \\
\text { Bentuk } \\
\text { kunjungan : } \\
\text { bersama teman } \\
\text { keluarga, rekan- } \\
\text { rekan perusahaan }\end{array}$ \\
\hline
\end{tabular}

\subsection{Strategi Perencanaan pengembangan pariwisata berkelanjutan}

\subsubsection{Strategi Kebijakan}

- Membuat pedoman umum serta pedoman pengelolaan objek wisata pantai Pangandaran yang lebih terfokus pada
Manajemen Wisatawan yang meliputi interprestasi dan pengaturan pola arus pengunjung.

- Membuka kesempatan bagi pihak swasta untuk berinvestas, serta Dinas Pariwisata Kabupaten melakukan promosi objek wisata dan menyatakan Pangandaran sebagai kawasan yang terbuka untuk investasi bisnis.

- Meningkatkan kualitas sumber daya manusia sekitar objek wisata sebagai modal dasar pengembangan melalui pelatihan dan pembekalan keahlian bidang pariwisata dan sosial budaya.

- Melakukan sosialisasi terhadap berbagai peraturan-peraturan (PERDA) yang terkait dengan pengembangan pariwisata yang berkelanjutan yang dilakukan baik oleh swasta, masyarakat maupun programprogram dari Dinas Pariwisata dan Budaya Kabupaten Ciamis.

\subsubsection{Strategi Fasilitas dan Aktivitas Wisata}

Untuk jumlah akomodasi yang ada diperlukan mengoptimalkan kualitas secara fisik bangunan dan pelayanan, sehingga tercapai standar pelayanan yang baik, dengan demikian diperlukan masukan-masukan dari pemerintah kepada para pengelola akomodasi sebagai rekomendasi peningkatan standar pelayanan hotel, sanitasi dan kepuasan konsumen. Diperlukan adanya perbaikan akses jalan, banyaknya fasilitas makan dan minum namun belum mencapai standar dalam hal sanitasi dan kesehatan, dengan demikian diperlukan pula pembuatan standar dan persyaratan fasilitas makan dan minum oleh pemerintah sehingga kondisinya lambat laun dapat menyesuaikan dengan standar tersebut.

\subsubsection{Strategi Pemasaran}

1. Strategi Produk.

Objek wisata pantai Pangandaran sebagai resort dengan multi atraksi, Strategi produk dapat dilakukan dengan menambahkan atraksi wisata yang unik dan menarik segmen yang lebih luas lagi, misalnya bagi kaum muda dapat menambahkan fasilitas parasailing dan bungee jumping yang dapat dikelola langsung oleh masyarakat.

\section{Strategi Harga}

Biaya wisata pantai Pangandaran ini masih sangat terjangkau oleh wisatawan dan sebanding dengan biaya yang dikeluarkan. Dapat dilakukan studi yang berkelanjutan mengenai perubahan pola perilaku pasar Pangandaran sehingga dapat lebih 
memberikan penyesuaian untuk harga yang pantas

3. Strategi Tempat (Place/Distribution)

Objek wisata pantai Pangandaran sudah ter'distribusi' dengan baik, meski banyak terdapat asumsi yang menyatakan pantai Pangandaran tidak semenarik dahulu, namun demikian pantai Pangandaran tetap menjadi objek wisata pantai yang paling populer di Jawa.

4. Strategi Promosi

Objek wisata Pangandaran masih termasuk minim, tidak ditemukan promosi tersendiri seperti memiliki home page khusus pantai Pangandaran, hanya terdapat sedikit mengenai pangandaran dalam web site SMK 1 Ciamis.

\section{KESIMPULAN REKOMENDASI}

5.1. Kesimpulan

Objek wisata pantai Pangandaran merupakan objek wisata yang sangat popular di kalangan wisatawan domestik (Nusantara) sebagai daerah tujuan wisata yang sangat kuat, sehingga objek wisata pantai Pangandaran masih memiliki peluang untuk menjadi sebuah destinasi wisata unggulan di Jawa Barat.

Berdasarkan hasil evaluasi terhadap kondisi produk wisata dan pasar aktual, objek wisata pantai Pangandaran, dalam hal kerusakan sarana prasarana, kesemerawutan pantai cukup kompleks, pantai Pangandaran tengah mencapai fase stagnasi dalam daur siklus hidup objek wisata, dimana fase stagnasi ini harus dapat diperbaiki sehingga tidak terjerembab dalam waktu singkat dalam fase kemunduran (decline),

Berdasarkan hasil evaluasi terhadap kondisi produk wisata dan pasar aktual, objek wisata pantai Pangandaran dalam hal kerusakan sarana dan prasarana kesemrawutan pantai cukup komplek, pantai Pangandaran tengah mencapai fase stagnasi dalam daur siklus hidup objek wisata.

Optimalisasi penyiapan sarana dan prasarana untuk mendukung pengembangan wisata bahari, seperti penyediaan alat selam, papan penunjuk tempat wisata, alat snorkeling, penjaga/polisi pantai, termasuk information center, penyediaan toilet, dan tempat sampah yang memadai bagi pengunjung yang membutuhkan.

\subsection{Rekomendasi}

Untuk dapat melaksanakan pengembangan wisata bahari, berikut merupakan rekomendasi yang dapat diberikan diantaranya dengan mengoptimalkan sub variable atraksi, amenitas, akssesibilitas dari perencanaan (pengambangan) wisata untuk lebih efektif terhadap keberhasilan pengembangan wisata bahari termasuk segala tema event kegiatan yang dilaksanakan.

Untuk mengoptimalkan Ancillary Services Pemerintah daerah perlu untuk mengalokasikan dana yang cukup untuk pengembangan pariwisata yang merupakan sector unggulan daerah, dengan melakukan koordinasi dengan semua stake holder.

Pengelolaan usaha objek dan daya tarik wisata (atraksi wisata) yang berbasis masyarakat di tiap desa penyediaan sarana wisata seperti homestay, cottage, restoran, penjualan

Pemerintah perlu menjalin kerjasama yang lebih baik dan berkelanjutan dengan pihak-pihak yang kompeten dan berpengalaman dibidang pariwisata seperti diving centre, travel, hotel, akademisis dalam pengembangan pemahaman, komunikasi dan edukasi pembangunan pariwisata bahari.

\section{DAFTAR PUSTAKA}

A. Black, James.1999, Metoda dan Masalah Penelitian Sosial, PT. Refika Aditama, Bandung.

Butler R.1992. Alternative Tourism : The Thin Edge of the Wedge, dalam Smith dan Eadington (1992) Tourism Alternative, Potentials and Problems in The Development of Tourism. University of Pensylavinia, Philadelphia.

Clarke J \& Godfrey K. 2000, The Tourism Development Handbook : A Practical Approach To Planning and Marketing. Continuum, London.

Dahuri. R, Rais J; Ginting SP; Sitepu. 2001, Pengelolaan Sumber Daya Wilayah Pesisir dan Lautan Secara Terpadu. PT. Pradnya Paramita, Jakarta.

Fandeli, Chafid, 2002, Perencanaan Kepariwisataan Alam. Fakultas Kehutanan Gajah Mada. Pustaka Pelajar, Yogyakarta.

Goeldner R, Ritchie B.R.J; McIntosh W.R. 2000, Tourism : Principles, Practices, Philosophies. Jon Willey \& Sons, Canada.

Gunn C. 1994, Tourism Planning; Basic, Concepts and Cases, Taylor and Francis, USA.

Inskeep Edward, 1998, Guide for local Authorities on Developing Sustainable Tourism. World Tourism Organization, New York. 
Kotler, Bowen, Makens, 1999, Marketing For Hospitality And Tourism, $2^{\text {nd }}$ Edition, Prentice-Hall, Inc. USA

Kartajaya, Hermawan., Yuswohadi, Sunarto, 2005, Attracting Tourists, Traders, Investors, Strategi Memasarkan Daerah di Era Otonomi Daerah.Gramedia Pustaka Utama, Jakarta.

Litbang Kompas, 2006

McInteyre George, 1993, Sustainable Tourism Development, Guide for Local Planners. World Tourism Organization.

Midleton Victor T C. 1998. Sustainable Tourism : A Marketing Perspective. Buttenworth-Heinemann.

Moleong J,Lexy. 1999, Metodologi Penelitian Kualitatif, Remaja Rosdakarya, Bandung.

Kartajaya, Hermawan; Yuswohadi, Sunarto, 2005, Attracting Tourists, Traders, Investors, Strategi Memasarkan Daerah di Era Otonomi Daerah. Gramedia Pustaka Utama, Jakarta.

Ristanto, Hari. 2002. Diktat Perencanaan Pariwisata. Manajemen Kepariwisataan. Sekolah Tinggi Pariwisata Bandung.

SuDjana, 2002, Metoda Statistika, Tarsito, Bandung.

Tjiptono, Fandy ; 2000, Strategi Pemasaran, ANDI, Yogyakarta.

Woodley, Alison. 1993. Tourism and Sustainable Development : The
Community Perspective. Department of Geography Series, University of Waterloo.

WTO, World Tourism Organization Agenda 2, 1992.

\section{Jurnal Online}

Siklus Hidup Objek Wisata : Studi Kasus Pulau Simeulue dan Pantai Pangandaran, Fictor Ferdinand, Ssi; Yosep Purnama, 12 November 2004, www.aseanjournal.com

Pengembangan Pariwisata Indonesia, Setyanto P. Santosa, 14 Pebruari 2002,http://kolom.pacific.net.id/ind/

Pariwisata Berkelanjutan : Prinsip-prinsip Pembangunan Pariwisata Berkelanjutan, Pusat Penelitian Kepariwisataan ITB, www.p2par.itb.ac.id

Analisis Jalur dan Strategi Pemasaran Kunjungan Wisman Sebelum dan Setelah Berkunjung ke Indonesia, Joko Darmoyo, www.budpar.go.id

\section{Dokumen-Dokumen}

RUTR Kawasan Pangandaran, DIPARDA Kabupaten Ciamis.

PERDA-PERDA Kawasan Wisata Pangandaran.

RENSTRA (Rencana Strategik) Tahun 2004 2009, Dinas Pariwisata dan Kebudayaan Kabupaten Ciamis. 
